\title{
Application of the DIY carbon footprint calculator to a wastewater treatment works
}

\author{
Siva Chetty ${ }^{1 *}$ and Kaverajen Pillay ${ }^{2}$ \\ 'Principal Water Technology Consultant: Royal HaskoningDHV, 6 Payne Street, Pinetown, 3610 \\ ${ }^{2}$ Acting Works Area Engineer, eThekwini Water and Sanitation, PO Box 1038, Durban, 4000
}

\begin{abstract}
The provision of water and wastewater treatment services exerts a huge operational cost on public financial resources. A substantial portion of the operational budget is made up of carbon-intensive energy costs. Energy is consumed in this sector in pumping, aeration, motor drives, administration, transportation and in the manufacture of chemicals such as polyelectrolyte, chlorine and ozone. The high electrical power consumption exerts added pressure on the environment in terms of greenhouse gas emissions. In order to manage the energy budget and develop climate-friendly technological options, Royal HaskoningDHV (RHDHV) has developed a do-it-yourself (DIY) Excel-based carbon footprint calculator to estimate the carbon equivalent emissions for a waterworks, a wastewater treatment works or a pumping station. The DIY carbon calculator computes Scope 1, Scope 2 and Scope 3 emissions. The DIY calculator starts with establishing the baseline carbon footprint of a works and shows the relative carbon equivalent emissions for different treatment stages. The next step involves the development of strategies to reduce the carbon footprint. Inherent within a wastewater treatment works is its ability to potentially generate its own 'green' energy by using anaerobically produced methane gas as a green energy alternative. This investigation demonstrates how the baseline carbon footprint of a wastewater treatment works can be reduced by considering viable options such as biogas to power generation, process re-design and drives to improve energy efficiency. Results show that the carbon calculator was able to demonstrate the effectiveness of carbon-reducing strategies in this energy-intensive sector. This further implies that the carbon calculator can be used as an additional management and decision support tool to assist an organisation towards a low carbon footprint.
\end{abstract}

Keywords : carbon footprint calculator, carbon equivalent emissions, greenhouse gas, green energy, Scope 1, 2 and 3 emissions, emission factor, sustainability, energy factory

\section{INTRODUCTION}

The treatment of wastewater can impact significantly on the global environment and the economy in terms of its contribution to greenhouse gases. From an energy point of view, wastewater treatment works (WWTW), consume a significant amount of energy derived from fossil fuels. With the recent climate change focus, the escalating cost of electricity and the need to reduce the carbon footprint of an organisation or an activity, the wastewater treatment works is viewed dualistically as a challenge and an opportunity.

The challenge in a WWTW is the amount of energy consumed, directly and indirectly, to achieve its final effluent discharge standards. It has been reported (Guo et al., 2009) that as much as $25 \%$ of the cost of treatment is attributable to energy costs, primarily in the form of electricity. The use of electricity from a non-renewable resource such as coal is a problem in terms of climate change impact. Related processes and services executed in the course of treatment such as use of chemicals, fuel for travel and operations, consumption of paper, disposal of residual waste and release of biogas exert a carbon footprint on the global environment. The DIY carbon footprint tool has been developed to compute an organisation's direct and indirect emissions. The DIY carbon footprint

This paper was originally presented at the 2014 Water Institute of Southern Africa (WISA) Biennial Conference, Mbombela, 25-29 May 2014.

* To whom all correspondence should be addressed.

e-mail: siva.chetty@rhdhv.com tool is a first step towards quantifying how much carbonequivalent emissions $\left(\mathrm{CO}_{2}\right.$ eq.) a WWTW is responsible for per cubic metre of wastewater treated. Once the computation has been undertaken, the next step is to identify opportunities to reduce the carbon footprint on a systematic and continuous basis.

The wastewater environment inherently holds the opportunity to reduce its carbon footprint. It has been postulated that a treatment works has the potential to be an 'energy factory', or a net generator of up to 10 times the amount of energy it consumes. The DIY carbon footprint tool is the first step towards realising the energy-generating potential in a WWTW. The DIY carbon footprint tool also gives meaning to the adage that 'what you can measure, you can manage'!

\section{METHODS}

The carbon footprint for a WWTW is computed using a do-ityourself (DIY) carbon footprint (CF) calculator. The DIY CF calculator operates on a Microsoft Excel macro-driven spreadsheet. The user can select an organisation or a sub-unit of an organisation such as a WWTW. The main building blocks of the calculus consist of input data, output data, transformation, conversions, emission factors, individual reports and integrated reports. The tool is also able to run a calculation and e-mail it to a targeted recipient. 


\section{Input data}

Input data covers the treatment works' process and operational parameters, a sample of which is reported in Table 1. Input values can be chosen for different intervals of time (day, month, and year).

\section{Emission factors}

The emission factors are used to compute the carbon equivalent emissions represented as $\mathrm{CO}_{2}$ eq. For a particular activity $\mathrm{Ai}$, the carbon equivalent emissions are represented by the equation:

$\mathrm{Ai}=$ emission factor ${ }^{*}$ consumption
The application of some of the emission factors is shown in Tables 2 and 3.

\section{Carbon dioxide equivalent emissions}

The carbon footprint is calculated from the greenhouse gas (GHG) protocol (Govender and Meijer, 2012) which is based on the Intergovernmental Panel on Climate Change (IPCC) guidelines.

In the process of wastewater treatment, carbon dioxide $\left(\mathrm{CO}_{2}\right)$, methane $\left(\mathrm{CH}_{4}\right)$ and nitrous oxide $\left(\mathrm{N}_{2} \mathrm{O}\right)$ are released, all of which have $\mathrm{CO}_{2}$ equivalent $\left(\mathrm{CO}_{2}\right.$ eq.) burden on the global warming potential(GWP). The greenhouse potential (GHP) of methane and nitrous oxide have 25 and 298 times the global (1) warming potential of $\mathrm{CO}_{2}$ respectively (Gupta and Singh, 2012).

\begin{tabular}{|c|c|c|c|c|}
\hline \multicolumn{5}{|c|}{$\begin{array}{c}\text { TABLE } 1 \\
\text { Input parameters for carbon footprint calculation }\end{array}$} \\
\hline & & Parameter & Unit & Value $^{(1)}$ \\
\hline & & Total inflow & $\mathrm{M} \ell /$ month & 1830 \\
\hline & & Biochemical oxygen demand (BOD) (influent) & $\mathrm{mg} / \mathrm{l}$ & 350 \\
\hline & & Chemical oxygen demand (COD) (influent) & $\mathrm{mg} / \ell$ & 600 \\
\hline & & Total Kjeldahl nitrogen (TKN) (influent) & $\mathrm{mg} / \mathrm{l}$ & 45 \\
\hline & & Biogas (direct release) & $\mathrm{m}^{3} / \mathrm{month}$ & 0 \\
\hline & & Biogas (flared) & $\mathrm{m}^{3} /$ month & 0 \\
\hline \multicolumn{5}{|c|}{ Scope No } \\
\hline \multirow[t]{4}{*}{1} & 1.1 & Coal consumption & $\mathrm{t} / \mathrm{month}$ & 0 \\
\hline & 1.2 & Diesel consumption in vehicles & l/month & 2240 \\
\hline & 1.3 & Petrol consumption in vehicles & e/month & 5600 \\
\hline & 1.4 & Fluidised bed reactor (FBR) incineration of sludge: dry & dry $\mathrm{t} / \mathrm{month}$ & 0 \\
\hline \multirow[t]{2}{*}{2} & 2.1 & Electricity & $\mathrm{kWh} / \mathrm{month}$ & 666000 \\
\hline & 2.2 & Potable water consumed & $\mathrm{kl} / \mathrm{month}$ & 3000 \\
\hline \multirow[t]{4}{*}{3} & & Consumables & & \\
\hline & 3.1 & Chlorine & $\mathrm{kg} /$ month & 5400 \\
\hline & 3.2 & Polyelectrolyte & $\mathrm{kg} /$ month & 2697 \\
\hline & 3.3 & Paper consumed & $\mathrm{kg} /$ month & 15 \\
\hline
\end{tabular}

${ }^{(1)}$ Typical input values for Northern WWTW (July 2013)

\begin{tabular}{|c|c|c|}
\hline \multicolumn{3}{|c|}{$\begin{array}{c}\text { TABLE } 2 \\
\text { Emission factors for consumables used in wastewater treatment }\end{array}$} \\
\hline Carbon dioxide generating consumables & Unit & $\mathbf{k g ~ C O}$ \\
\hline \multicolumn{3}{|l|}{ Transport } \\
\hline Diesel & $\ell$ & 2.66 \\
\hline Petrol & $\ell$ & 2.32 \\
\hline \multicolumn{3}{|l|}{ Energy \& Fuel } \\
\hline Coal CV & $\mathrm{MJ} / \mathrm{kg}$ & 26.00 \\
\hline Coal & $\mathrm{kg} \mathrm{CO}_{2} / \mathrm{MJ}$ & 0.087 \\
\hline Power & $1 \mathrm{kWh}$ & 0.99 \\
\hline \multicolumn{3}{|l|}{ Chemicals } \\
\hline Chlorine & $\mathrm{kg}$ & 0.68 \\
\hline Sodium hydroxide & $\mathrm{kg}$ & 0.96 \\
\hline Polyelectrolyte & $\mathrm{kg}$ & 1.15 \\
\hline Aluminium sulphate & $\mathrm{kg}$ & 0.51 \\
\hline
\end{tabular}


In the process of $\mathrm{COD}$ treatment, a certain amount of $\mathrm{CH}_{4}$ is released ( $0.0085 \mathrm{~kg} \mathrm{CH}_{4} / \mathrm{kg}$ COD treatment, see Table 3$)$. The $\mathrm{CO}_{2}$ eq. is then 25 times the global warming potential of $\mathrm{CH}_{4}$. Although $\mathrm{CO}_{2}$ is also released in the course of $\mathrm{COD}$ reduction, it is not taken into account as the $\mathrm{CO}_{2}$ is considered biogenic (Gupta et al., 2012) as the $\mathrm{CO}_{2}$ is consumed through photosynthesis in the food production process.

For electrical power consumption, the emission factor used is $0.99 \mathrm{~kg} \mathrm{CO}_{2}$ per $\mathrm{kWh}$ consumed in the South African context. In the USA and Europe the emission factor for electrical energy can be as low as $0.55 \mathrm{~kg} \mathrm{CO}_{2}$ per $\mathrm{kWh}$ due to a more efficient power production process which is achieved by combined heat and power (CHP) production.

\section{Scope of emissions}

The tool measures 3 different scopes of carbon emissions (Table 4). Scope 1 emissions are those emissions an organisation is

\begin{tabular}{|c|c|c|c|c|}
\hline \multicolumn{5}{|c|}{$\begin{array}{c}\text { TABLE } 3 \\
\text { Emission factors for wastewater treatment }\end{array}$} \\
\hline Emissions related to wastewater treatment processes & Unit & $\mathrm{N}_{2} \mathrm{O}$ & $\mathrm{CH}_{4}$ & $\begin{array}{l}\mathrm{CO}_{2} \text { eq. } \\
\text { factor }\end{array}$ \\
\hline Nitrogen treatment & $\mathrm{kg}$ TKN & 0.01 & & 298 \\
\hline Carbon treatment & $\mathrm{kg} C O D$ & & 0.0085 & 25 \\
\hline Nitrogen treatment & $\mathrm{kg} \mathrm{N}$ total & 0.015714 & & 298 \\
\hline Biogas & $\mathrm{m}^{3} / \mathrm{d}$ & 0.0023 & 0.0233 & \\
\hline Transportation of chemicals & $\mathrm{kg} / \mathrm{d}$ & & & 0.013 \\
\hline \multirow[t]{2}{*}{ Incineration of waste } & $\begin{array}{l}\mathrm{kg} / \text { ton dry } \\
\text { solids }\end{array}$ & 0.99 & & 298 \\
\hline & $\begin{array}{l}\mathrm{kg} / \text { ton dry } \\
\text { solids }\end{array}$ & & 1.1 & 25 \\
\hline Transportation of waste to hazardous waste disposal site & $\mathrm{kg} / \mathrm{d}$ & & & 0.0011 \\
\hline Transportation of waste to general disposal site & $\mathrm{kg} / \mathrm{d}$ & & & 0.0011 \\
\hline
\end{tabular}

\begin{tabular}{|c|c|}
\hline \multicolumn{2}{|c|}{$\begin{array}{c}\text { TABLE } 4 \\
\text { Carbon equivalent emissions }\end{array}$} \\
\hline Name of organisation & eThekwini Municipality \\
\hline 2013 Carbon Footprint Study & 30 January 2014 \\
\hline Name of sub-unit & Northern WWTW \\
\hline \multicolumn{2}{|c|}{ Carbon equivalent emissions (kg/month) } \\
\hline Coal consumption & 0.00 \\
\hline Diesel consumption vehicles & 5958.40 \\
\hline Petrol consumption vehicles & 12992.00 \\
\hline FBR incineration of sludge & 0.00 \\
\hline Treatment of wastewater & 458415.00 \\
\hline Discharge of wastewater & 68096.91 \\
\hline Flaring of biogas & 0.00 \\
\hline Total: Scope 1 & 545462.3 \\
\hline Electricity: Scope 2 & 181764.00 \\
\hline Potable water: Scope 2 & 1809.00 \\
\hline Total: Scope 2 & 183573.00 \\
\hline Chemicals & 6773.55 \\
\hline Transportation of chemicals & 105.26 \\
\hline Incineration of wastewater sludge & 0.00 \\
\hline Transportation of waste & 734.06 \\
\hline Transportation of sludge & 1981.97 \\
\hline Commute: home to work & 7866.00 \\
\hline Paper usage & 28.61 \\
\hline Total: Scope 3 & 17489.45 \\
\hline Scope $1+$ Scope $2+$ Scope 3 & 746524.76 \\
\hline
\end{tabular}

http://dx.doi.org/10.4314/wsa.v41i2.12

Available on website http://www.wrc.org.za

ISSN 1816-7950 (On-line) $=$ Water SA Vol. 41 No. 2 WISA 2014 Special Edition 2015

Published under a Creative Commons Attribution Licence 
directly responsible for, such as fuel consumption in the treatment works, emissions due to aerobic or anaerobic treatment processes, and incineration of sludge. Scope 2 emissions are those measured according to the energy use of a company where the energy is supplied by a utility such as South Africa's state-owned power utility, Eskom. Scope 3 emissions are those for which an organisation is indirectly responsible, such as emissions produced during the manufacturing process of chemicals that are purchased by a WWTW. The chemicals typically used in a WWTW are polyelectrolyte, chlorine and aluminium sulphate.

\section{Key features of the DIY CF tool}

The tool could be used to measure the carbon footprint of a multitude of treatment works in a municipality or a water treatment plant and its distribution network. It enables easy computation of a baseline and thereafter generation of various options aimed at reducing an organisation's carbon footprint. The tool can establish where the most emissions are generated and implement strategies to reduce them. The tool provides a package of interventions which can be considered to reduce the carbon footprint in a WWTW.

\section{Case studies}

The CF tool was used to compute the base case (the situation as of July 2013) for the Northern and KwaMashu WWTWs in the eThekwini Municipality.

The Northern WWTW (NWWTW) has an installed capacity of $70 \mathrm{Ml} / \mathrm{d}$ with current average dry weather flow of $60 \mathrm{Ml} / \mathrm{d}$. The NWWTW key unit operations consist of primary sedimentation, activated sludge treatment and anaerobic digestion. The secondary effluent is clarified in a system of secondary clarifiers and then discharged into the environment after chlorination. The waste activated sludge from the aerobic process and the primary sludge are anaerobically digested in 3 anaerobic digesters. The digesters are heated to mesophillic temperature $\left(37^{\circ} \mathrm{C}\right)$ using about $40 \%$ of the biogas generated. The remaining biogas, comprising of approximately $65 \% \mathrm{CH}_{4}$ and $25 \% \mathrm{CO}_{2}$ is flared to atmosphere. The digested sludge is dewatered and transported to land application. Electricity is used primarily in the aeration plant and for pumping equipment throughout the works. The power consumption at the activated sludge plant is about $480000 \mathrm{kWh} /$ month which is about $70 \%$ of the treatment works' total consumption.

The KwaMashu WWTW (KWWTW) has an installed capacity of $70 \mathrm{M} \ell / \mathrm{d}$, comprising of a conventional $50 \mathrm{M \ell} / \mathrm{d}$ activated sludge plant and a $15 \mathrm{Ml} / \mathrm{d}$ bio-filter plant. The current average dry weather flow is about $60 \mathrm{Ml} / \mathrm{d}$. The KWWTW's key unit operations consist of primary sedimentation, activated sludge treatment, bio-filtration and anaerobic digestion. The secondary effluent is clarified in a system of secondary clarifiers and then discharged into the environment after chlorination. The waste activated sludge from the aerobic process is thickened and dewatered using belt presses. A portion of the primary sludge (30\%) is dewatered and incinerated in a fluidised bed reactor (FBR). The remaining primary sludge is anaerobically digested in 2 digesters. The digesters are heated to mesophilic temperature $\left(37^{\circ} \mathrm{C}\right)$ using about $40 \%$ of the biogas. The remaining biogas, comprising of approximately $65 \%$ methane and $25 \% \mathrm{CO}_{2}$ is flared to atmosphere. The digested sludge is dewatered and stockpiled on site. Electricity is used primarily in the aeration plant and in pumping equipment throughout the works. Coal is used in the FBR to support the combustion process. The works consume chlorine and polyelectrolyte in the treatment process.

\section{RESULTS AND DISCUSSION}

The CF for the Northern WWTW was computed using operational and process data for July 2013 and is reported in Table 5. The CF for the KwaMashu WWTW was also computed using operational and process data for July 2013, and is shown in Table 8.

At Northern WWTW, the major emissions are due to treatment of wastewater (33\%), discharge of treated water (4.7\%), flaring of biogas (14\%) and electricity consumption (45.7\%). The $\mathrm{CF}$ tool points to the major emission sources and highlights potential areas of focus. The primary objective of wastewater treatment is for carbon and nitrogen reduction, as a result of which carbon dioxide and residual levels of nitrous oxide and methane are released. Carbon dioxide is not accounted for in the net contribution to greenhouse gases as it is largely derived from the food chain. Crops consume carbon dioxide from the atmosphere and build cell mass such as carbohydrates and sugars through the process of photosynthesis. The residual organic matter in wastewater is represented as COD. The breakdown of $\mathrm{COD}$ in wastewater will produce $\mathrm{CO}_{2}$ which in turn is cycled back into the food chain. The IPCC has declared that $\mathrm{CO}_{2}$ releases in the food chain are not considered as a contributor to GWP (Gupta et al., 2012). However, methane and nitrous oxides do contribute to the GWP as they have much longer cycling times on earth (greater than 100 years) and so they are accounted for.

The process-related emissions values, made up of $\mathrm{N}_{2} \mathrm{O}, \mathrm{CH}_{4}$ and $\mathrm{CO}_{2}$ eq. values, are shown in Table 6 .

Although the $\mathrm{N}_{2} \mathrm{O}$ contribution appears relatively small compared to $\mathrm{CH} 4$, its global warming potential is magnified 298 times to be equivalent to $1 \mathrm{~kg}$ of $\mathrm{CO}_{2}$. Similarly the $\mathrm{CH}_{4}$ contribution has a factor 25 contribution to be $\mathrm{CO}_{2}$ equivalent. In the net contribution to $\mathrm{CO}_{2}$ eq. emissions, $\mathrm{N}_{2} \mathrm{O}$ and $\mathrm{CH}_{4}$ account for $51 \%$ and $49 \%$, respectively, of the process-related emissions under the wastewater treatment category within Scope 1 emissions, for NWWTW. The discharge of wastewater accounts for less than $5 \%$ of total emissions, mainly contributed by $\mathrm{N}_{2} \mathrm{O}$ emissions. The discharge-based $\mathrm{CO}_{2}$ eq. contribution is a function of treatment; if there is poor reduction in nitrogen as represented by Total Kjeldahl Nitrogen (TKN), then the $\mathrm{CO}_{2}$ eq. emissions will increase. Flaring of biogas is made up of $\mathrm{N}_{2} \mathrm{O}$ and $\mathrm{CH}_{4}$ residual gases in the flared gas stream. The flaring of biogas accounts for $14.9 \%$ of the total $\mathrm{CO}_{2}$ eq. emissions. If the biogas were to be discharged directly to the atmosphere, then the methane component of biogas (65\% volume basis) would have to be accounted for.

The reduction in $\mathrm{CO}_{2}$ eq. emissions for the NWWTW between the current situation and Option 1 is shown in Fig. 1 and Table 7 . The total emissions reduce by $47 \%$. The reduction between current emissions and Option 1 emissions is 26\%,72\% and $4 \%$ for Scope 1 , Scope 2 and Scope 3 emissions respectively. The significant contributor to Scope 2 emission reduction is a scenario whereby biogas is used for electricity generation with no flaring of biogas.

Currently, about $40 \%$ of the biogas is consumed in heating the digester to mesophilic temperature. If the biogas of 5500 $\mathrm{m}^{3} / \mathrm{d}$ were to be used for electricity generation in a combined heat and power system (CHP), there would be maximal energy 


\begin{tabular}{|c|c|c|}
\hline \multicolumn{3}{|c|}{$\begin{array}{c}\text { TABLE } 5 \\
\text { Carbon footprint study for Northern WWTW }\end{array}$} \\
\hline 2013 Carbon Footprint Study & & \\
\hline Options & Current situation: Biogas to flare & $\begin{array}{c}\text { Possible biogas to electricity; improved } \\
\text { dewatering }\end{array}$ \\
\hline Name of sub-unit & NWWTW & NWWTW \\
\hline Carbon equivalent emissions & $\mathrm{kg} / \mathrm{month}$ & $\mathrm{kg} / \mathrm{month}$ \\
\hline Coal consumption & 0 & 0 \\
\hline Diesel consumption vehicles & 5958 & 5958 \\
\hline Petrol consumption vehicles & 12992 & 12992 \\
\hline FBR incineration of sludge & 0 & 0 \\
\hline Treatment of wastewater & 477081 & 477081 \\
\hline Discharge of wastewater & 68097 & 68097 \\
\hline Flaring of biogas & 200865 & 0 \\
\hline Total: Scope 1 & 764993 & 564128 \\
\hline Electricity: Scope 2 & 659340 & 181764 \\
\hline Potable water: Scope 2 & 1809 & 1809 \\
\hline Total: Scope 2 & 661149 & 183573 \\
\hline Chemicals & 6774 & 6774 \\
\hline Transportation of chemicals & 105 & 105 \\
\hline Incineration of wastewater sludge & 0 & 0 \\
\hline Transportation of waste (screenings) & 734 & 734 \\
\hline Transportation of sludge & 2643 & 1982 \\
\hline Commute: home to work & 7866 & 7866 \\
\hline Paper usage & 29 & 29 \\
\hline Total: Scope 3 & 18150 & 17489 \\
\hline Scope $1+$ Scope $2+$ Scope 3 & 1444292 & 765191 \\
\hline
\end{tabular}

\begin{tabular}{|c|c|c|c|}
\hline \multicolumn{4}{|c|}{$\begin{array}{c}\text { TABLE } 6 \\
\text { Process-related emissions: NWWTW }\end{array}$} \\
\hline & $\begin{array}{c}\mathrm{N}_{2} \mathrm{O} \\
(\mathbf{k g} / \\
\text { month) }\end{array}$ & $\begin{array}{c}\mathrm{CH}_{4} \\
\text { (kg/ } \\
\text { month) }\end{array}$ & $\begin{array}{l}\mathrm{CO}_{2} \text { eq. }{ }^{(1)} \\
\text { (kg/month) }\end{array}$ \\
\hline Treatment of wastewater & 824 & 9333 & 477081 \\
\hline Discharge of wastewater & 230.1 & Negligible & 68097 \\
\hline Flaring of biogas & 365.7 & 3704.7 & 5 \\
\hline
\end{tabular}

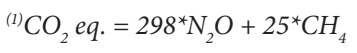

gain from the biogas in terms of electrical and thermal output. The heat from the reciprocating engines would be used to heat the anaerobic digesters and the electrical power would be used to feed into the works' electrical grid which partly reduces dependence on mains grid power supply.

\section{CHP versus conventional power generation}

Mains power is sourced from Eskom's coal-fired power stations with a carbon equivalent emission of $0.99 \mathrm{~kg} \mathrm{CO}_{2}$ per $\mathrm{kWh}$ electricity generated. A conventional power station is less efficient than a CHP system. The comparison is illustrated in Fig. 2. There is an overall improvement in efficiency in a CHP system compared to a conventional power station system. By way of illustration, in a CHP system, from an input of 100 units

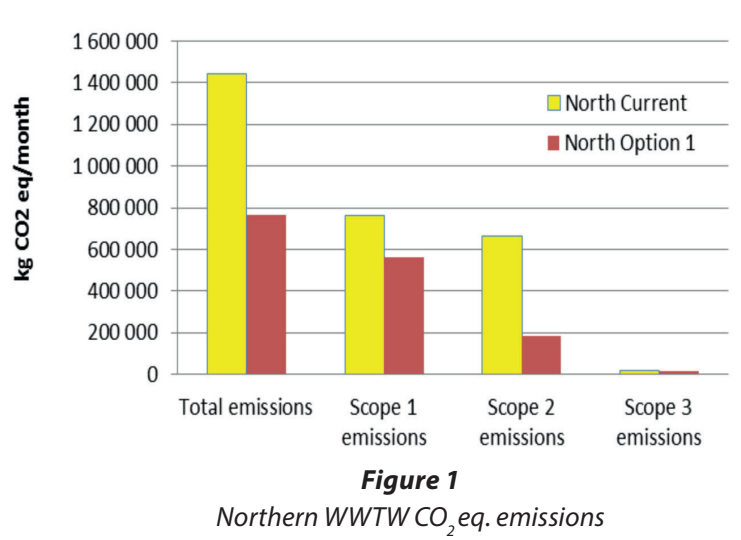

http://dx.doi.org/10.4314/wsa.v41i2.12

Available on website http://www.wrc.org.za

ISSN 1816-7950 (On-line) = Water SA Vol. 41 No. 2 WISA 2014 Special Edition 2015

Published under a Creative Commons Attribution Licence 
TABLE 7

Total and scope-based emissions: Northern WWTW

\begin{tabular}{|l|c|c|c|}
\hline Emission category & $\begin{array}{c}\text { Current emissions in } \mathbf{C O}_{\mathbf{2}} \text { eq. } \\
\text { (kg/month) }\end{array}$ & $\begin{array}{c}\text { Option 1 emissions in } \text { CO }_{\mathbf{2}} \text { eq. (kg/ } \\
\text { month) }\end{array}$ & Reduction in emissions (\%) \\
\hline Total emissions & 1444292 & 765191 & 47 \\
\hline Scope 1 emissions & 764993 & 564128 & 72 \\
\hline Scope 2 emissions & 661149 & 183573 & 4 \\
\hline Scope 3 emissions & 18150 & 17489 & 76 \\
\hline
\end{tabular}

TABLE 8

Carbon footprint study for KwaMashu WWTW

\begin{tabular}{|l|c|c|}
\hline Scenario & Current situation (coal, FBR) & Possible biogas to electricity \\
\hline Name of sub-unit: & KWWTW & KWWTW \\
\hline Carbon equivalent emissions: & $\mathrm{kg} / \mathrm{month}$ & 0 \\
\hline Coal consumption & 675072 & 12992 \\
\hline Diesel consumption vehicles & 5958 & 0 \\
\hline Petrol consumption vehicles & 12992 & 624536 \\
\hline FBR incineration of sludge & 48378 & 72562 \\
\hline Treatment of wastewater & 624536 & 0 \\
\hline Discharge of wastewater & 72562 & 716049 \\
\hline Flaring of biogas & 94748 & 508183 \\
\hline Total: Scope 1 & 1534246 & 1538 \\
\hline Electricity: Scope 2 & 840823 & 509720 \\
\hline Potable water: Scope 2 & 1538 & 7523 \\
\hline Total: Scope 2 & 842360 & 109 \\
\hline Chemicals & 8420 & 0 \\
\hline Transportation of chemicals & 119 & 1242657 \\
\hline Incineration of wastewater sludge & 0 & 73 \\
\hline Transportation of waste (screenings) & 73 & 1909 \\
\hline Transportation of sludge & 6313 & 7245 \\
\hline Commute: home to work & 7245 & 29 \\
\hline Paper usage & 29 & \\
\hline Total: Scope 3 & 22199 & \\
\hline Scope 1+ Scope 2 +Scope 3 & & \\
\hline & 2398806 & \\
\hline
\end{tabular}

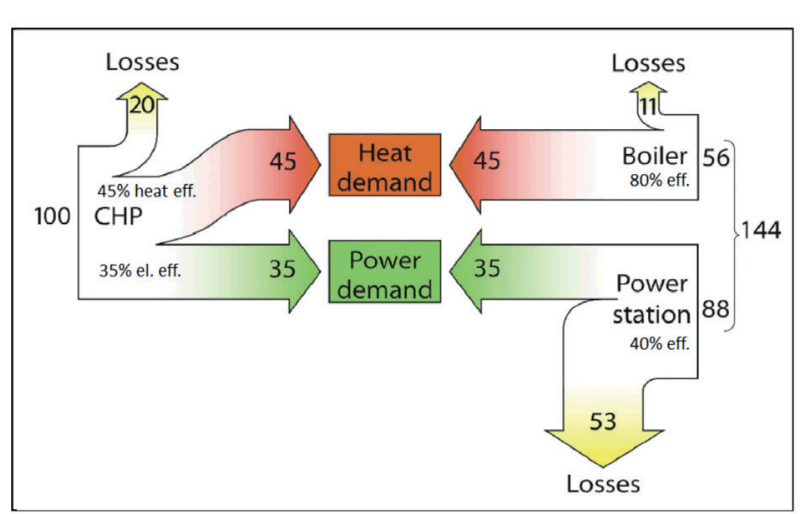

Figure 2

CHP versus conventional power station of energy, there is an output of 35 units of electrical energy and 45 units of thermal with an overall energy efficiency of $80 \%$. In contrast, for a power plant to achieve the same energy output as a CHP system, there has to be 144 units of energy input made up of 56 units of input to the boiler and 88 units of input to the power station, resulting in an overall efficiency of 55\%. By using the biogas, there is a net gain in energy conversion, which ultimately results in less $\mathrm{CO}_{2}$ eq. emissions. If Eskom's power stations operated on a CHP system, as in many European and American countries, then the energy utilisation efficiency would improve which would result in an almost $50 \%$ reduction in $\mathrm{CO}_{2}$ eq. emission per kWh generated. Currently, most Eskom thermal energy is vented to atmosphere.

The reduction in $\mathrm{CO}_{2}$ eq. emissions for KWWTW between the current situation and Option 1 is shown in Fig. 3. The total emissions reduce by $48 \%$. The reduction is made up of contributions in Scope 1 emissions (53\%), Scope 2 emissions (39\%) 
and Scope 3 emissions (24\%). The significant contributor to the Scope 2 emissions reduction is a scenario whereby biogas is used for electricity generation and no flaring of biogas takes place. The reduction in Scope 1 emissions is due to substituting coal feed to the FBR with a drier sludge. Under the current situation, coal is used as an energy supplement to support the combustion process. One possible option is to improve the total solids in the dewatered sludge from $18 \%$ to $24 \%$ total solids and to use the waste heat from the FBR emissions to dry the sludge cake further from $24 \%$ to $40 \%$ total solids. Under this option,

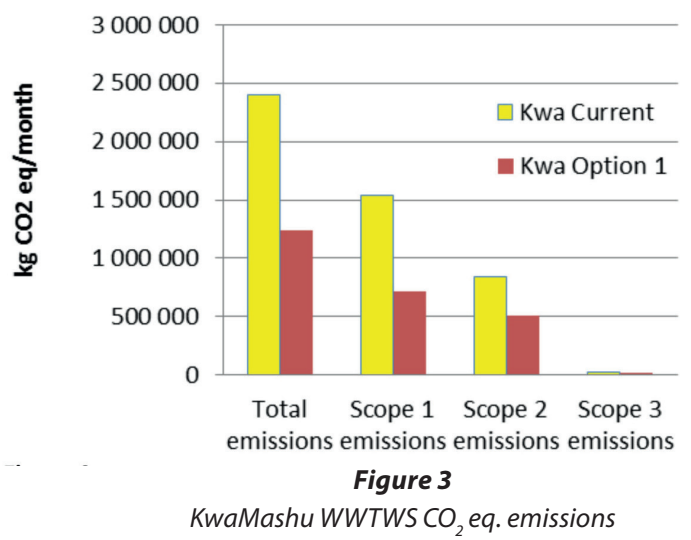

it is possible to avoid the use of coal and reduce $\mathrm{CO}_{2}$ emissions from the combustion of coal. The DIY carbon footprint tool is useful in showing how different options can be compared and contrasted. The reduction in Scope 3 emissions for KwaMashu WWTW is relatively greater than for Northern WWTW because the sludge dryer in Option 1 reduces the frequency of transporting sludge off site which results in a corresponding reduction in vehicle fuel consumption and lower $\mathrm{CO}_{2}$ eq. emissions.

The data for the KWWTW case study show that the use of biogas to electricity yields the maximum energy gain. The improved energy efficiency is shown in Fig. 3.

In Table 11 the percentage contribution to the $\mathrm{CO}_{2}$ eq. is shown for the current situation and a possible option. The actual values are shown in Table 8 . In the current situation, coal is used as an energy supplement to the FBR, and the digester biogas is flared. In Option 1, the $\mathrm{CO}_{2}$ eq. is computed under a scenario where biogas is used for electricity generation and coal is replaced with a drier sludge feed to the FBR. In the current situation, electricity usage, coal consumption, and treatment of wastewater account for $35 \%, 28 \%$ and $26 \%$ of the $\mathrm{CO}_{2}$ eq. contribution respectively. In Option 1, the major contribution to $\mathrm{CO}_{2}$ eq. emissions is treatment of wastewater and electricity consumption. The $\mathrm{CF}$ analysis shows how there is a shift from fuel-based emissions dominating the carbon footprint to emissions being dominated by wastewater treatment and electricity consumption.

\begin{tabular}{|l|c|c|c|}
\hline \multicolumn{4}{|c|}{ TABLE 9 } \\
\hline Emission category & $\begin{array}{c}\text { Current emissions in } \text { CO }_{\mathbf{2}} \\
\text { eq. (kg/month) }\end{array}$ & $\begin{array}{c}\text { Option } \mathbf{1} \text { emissions in } \mathbf{C O}_{\mathbf{2}} \\
\text { eq. (kg/month) }\end{array}$ & Reduction in emissions (\%) \\
\hline Total emissions & 2398806 & 1235653 & 48 \\
\hline Scope 1 emissions & 1534246 & 716049 & 53 \\
\hline Scope 2 emissions & 842360 & 509720 & 39 \\
\hline Scope 3 emissions & 22199 & 16887 & 24 \\
\hline
\end{tabular}

\begin{tabular}{|l|c|c|c|}
\hline \multicolumn{4}{|c|}{ TABLE 10 } \\
\hline & $\mathbf{N}_{\mathbf{2}} \mathbf{O}$ (kg/month) & $\mathbf{C H}_{\mathbf{4}}$ (kg/month) & $\mathbf{C O}_{\mathbf{2}}$ eq. (kg/month) \\
\hline Treatment of wastewater & 780.0 & 15746.2 & 624536 \\
\hline Discharge of wastewater & 245.1 & negligible & 72561 \\
\hline Flaring of biogas & 172.5 & 1747.5 & 94748 \\
\hline
\end{tabular}

$\mathrm{CO}_{2}$ eq. $=298^{*} \mathrm{~N}_{2} \mathrm{O}+25^{\star} \mathrm{CH}_{4}$

\begin{tabular}{|l|c|c|}
\hline \multicolumn{3}{|c|}{ TABLE 11 } \\
\hline & Current situation (coal, FBR) (\%) & Option 1: Possible biogas to electricity (\%) \\
\hline Coal consumption & 28.1 & 0.0 \\
\hline Diesel consumption vehicles & 0.2 & 0.5 \\
\hline Petrol consumption vehicles & 0.5 & 1.1 \\
\hline FBR incineration of sludge & 2.0 & 0.0 \\
\hline Treatment of wastewater & 26.0 & 50.5 \\
\hline Discharge of wastewater & 3.0 & 5.9 \\
\hline Flaring of biogas & 3.9 & 0.0 \\
\hline Electricity: Scope 2 & 35.1 & 41.1 \\
\hline
\end{tabular}




\section{Specific emissions}

The specific emissions, reported as $\mathrm{kg} \mathrm{CO}_{2}$ eq. per $\mathrm{m}^{3}$ treated, are shown in Fig. 4. KwaMashu and Northern WWTW have a specific CF emission of 1.23 and $0.79 \mathrm{~kg} \mathrm{CO}$ eq. $/ \mathrm{m}^{3}$ treated respectively. KwaMashu WWTW has 55\% higher emissions than Northern works due to its coal usage and higher electricity consumption. The relatively higher electricity consumption is due to pumping the large volume of raw sewage to the primary settling tanks which are on an elevated platform. In contrast, at Northern WWTW the flow to the primary sedimentation tanks is gravity fed. After considering biogas to electricity generation as an option, the specific $\mathrm{CO}_{2}$ eq. emissions normalise to between 0.637 and 0.418 for KwaMashu and Northern WWTWs respectively. The reduced specific emissions are comparable to previously reported work on specific $\mathrm{CO}_{2}$ eq. emissions as $0.773 \mathrm{~kg} \mathrm{CO}$ eq. $/ \mathrm{m}^{3}$ (Govender and Meijer 2012) and a United Kingdom reported figure of $0.7 \mathrm{~kg} \mathrm{CO}$ eq. $/ \mathrm{m}^{3}$ (Defra, 2011).

\section{Exploring energy saving in the activated sludge plant}

An activated sludge plant consumes a significant amount of nonrenewable energy in the form of electricity to transfer oxygen into the aeration plant. For Northern works, the power required for the aeration plant is as much as $70 \%$ of the total electrical power consumption. This plant accounts for a significant portion of the carbon footprint in the WWTW. There is the opportunity to optimise the oxygenation efficiency by considering the inter-related parameters of dissolved oxygen control, influent COD load trends, final effluent quality and time of day. CarCON software, developed by RHDHV, is an advanced process control system which optimises nutrient removal, minimises aeration energy and chemical consumption, and enhances treatment efficiency in a WWTW. If the aeration-based power consumption for Northern works is about $473766 \mathrm{kWh} /$ month out of the total of $666000 \mathrm{kWh} /$ month (July 2013), and assuming that CarCON control system can deliver a $10 \%$ saving in aeration energy, then through the CF DIY tool, there is a reduction of $47377 \mathrm{~kg} \mathrm{CO}_{2}$ eq. emissions per month, which is a saving of $7 \%$ in aerationbased $\mathrm{CO}_{2}$ eq. emissions.

CarCON predicts the required oxygenation capacity and adjusts the setpoint according to the measurements taken, such as ammonia, nitrate, oxygen, and phosphate (Fig. 5). This

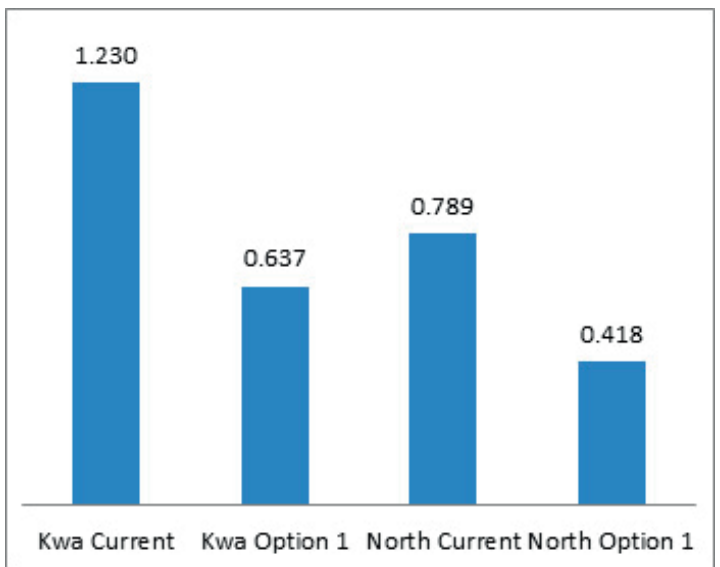

Figure 4

$\mathrm{CO}_{2}$ eq. specific emissions $\left(\mathrm{kg} \mathrm{CO}_{2} / \mathrm{m}^{3}\right.$ treated) system is useful in optimising the energy-intensive oxygenation process as a function of variable influent load during the diurnal and seasonal cycles.

\section{Energy factory concept}

The DIY carbon footprint tool is useful for analysing the energy pathways in wastewater treatment and seeking opportunities for reduction. The energy consumption in a WWTW can be up to $25 \%$ of operating and maintenance costs (Guo et al., 2009). In addition to the carbon footprint burden, there is an escalating burden in the cost of electricity and national pressure on the mains supply system. The DIY CF tool points to the areas of intensive $\mathrm{CO}_{2}$ eq. output. After exploiting biogas to electricity and heat generation in a CHP system, the $\mathrm{CO}_{2}$ eq. emissions (Fig. 1) show that there is a shift in the carbon footprint from Scope 2 emissions (electricity consumption) to Scope 1 emissions (wastewater treatment). This analysis presents an opportunity to investigate options to lower the carbon footprint involved in wastewater treatment. One opportunity lies in the fact that the anaerobic treatment process is more energy efficient that the aerobic process and the anaerobic process is a net generator of 'green' energy (Fig. 6). It has been suggested that, in theory, a treatment works has an inherent potential to generate up to 5 times the amount of energy it consumes (Guo et al., 2009). This is possible if more of the COD in the influent can be directed to the anaerobic digestion process. This can be partially achieved by improving the performance of the primary settling tanks to increase COD removal.

The data in Fig. 6 show that for every $100 \mathrm{~kg}$ of COD, the aerobic process consumes $60 \mathrm{~kW}$ of electrical energy for aeration, and generates about $40 \mathrm{~kg}$ biomass, whereas for the same $100 \mathrm{~kg}$ of COD input, the anaerobic digestion process generates a net equivalent of $280 \mathrm{KWh}$ energy and $5 \mathrm{~kg}$ biomass. It is possible to shift the status of a WWTW from a net consumer of non-renewable, fossil fuel energy to an 'energy factory' by systematically following these steps:

- Use biogas for electricity generation and heat recovery through a CHP system

- Introduce process control in the aeration plant (carCON) to

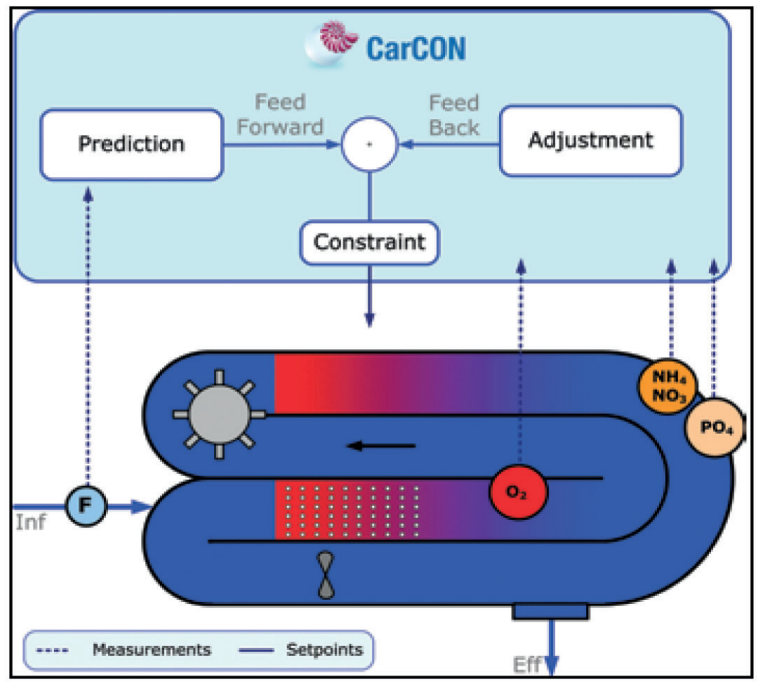

Figure 5

CarCON process optimisation concept 
reduce energy consumption

- Maximise COD treatment anaerobically rather than aerobically

- Undertake research on advanced anaerobic treatment on medium strength COD influents such as the upflow anaerobic sludge blanket (UASB) digester concept

The wastewater and water treatment sector is a substantial contributor to global GHGs in the form of carbon dioxide, methane and nitrous oxide. There are several possibilities which can reduce the cost of water and sanitation services and also reduce their carbon footprint. The toolbox of opportunities to reduce the carbon footprint in a WWTW is presented in Table 12.

The use of biogas for energy generation, coupled with combined heat and power (CHP) systems will drive up efficiency and reduce dependence on fossil fuel energy. Conventional power plants only convert $37 \%$ of the energy in fuels to useful energy in the form of electricity, the rest is transferred to the environment as heat.

\section{CONCLUSIONS}

The DIY carbon footprint tool developed for eThekwini Water and Sanitation is useful in terms of institution building, technical capacity building in carbon footprint assessment and for strategic planning in the era of the carbon market. The DIY carbon footprint tool is useful in educating the political, strategic, management and operational personnel involved in wastewater management particularly in the context of climate change mitigation efforts, the clean development mechanism and options for non-renewable energy consumption. The tool offers a scientific basis for considering the activities that

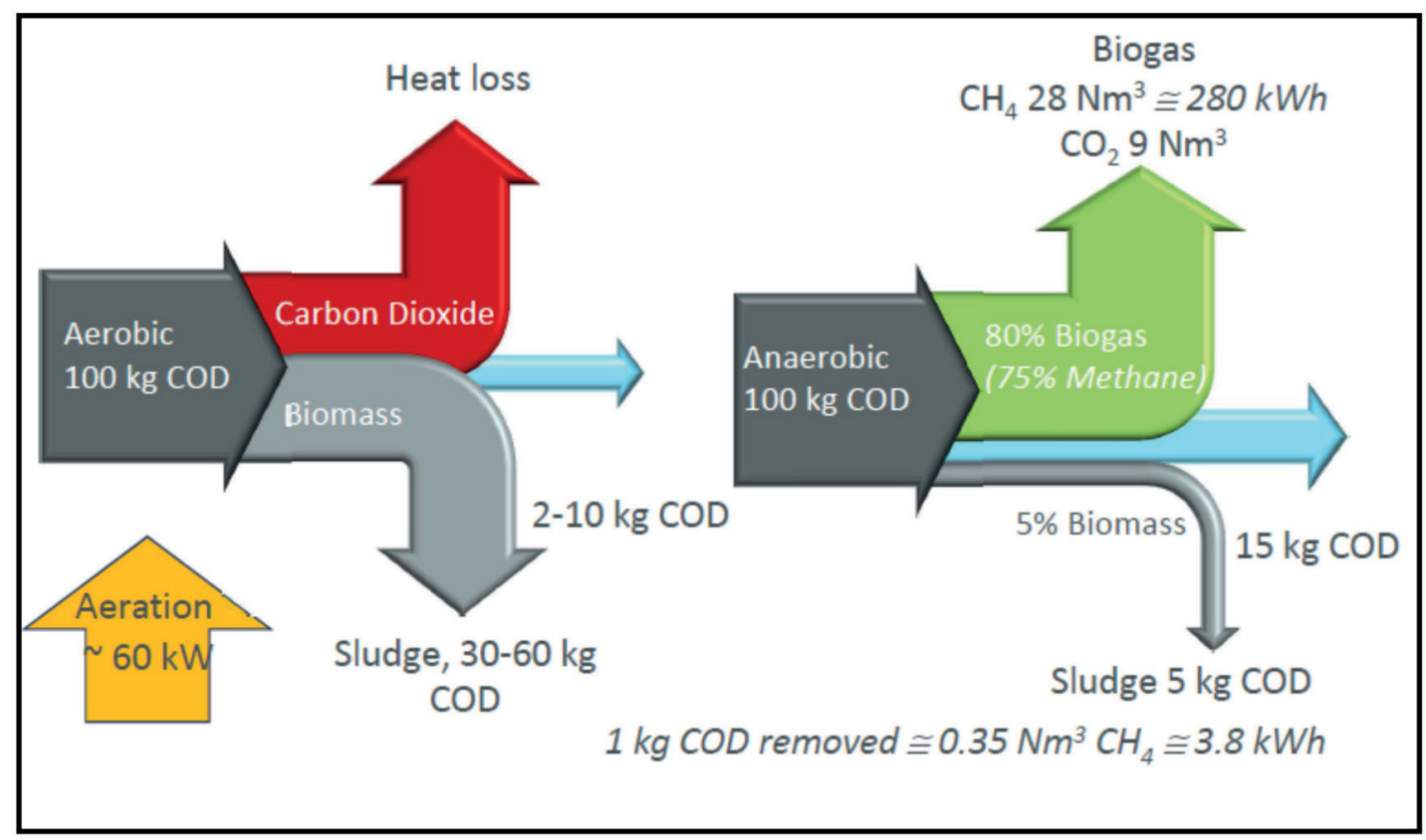

Figure 6

Energy flow: aerobic versus anaerobic processes

\begin{tabular}{|l|l|}
\hline \multicolumn{1}{|c|}{} & \multicolumn{1}{c}{ TABLE 12 } \\
\hline \multirow{5}{*}{ Efficiency drives } & Compressed air systems: use blowers for aeration instead of motorised aerators \\
\cline { 2 - 2 } & Introduce variable speed drives for pumps and aerators \\
\cline { 2 - 2 } & $\begin{array}{l}\text { Heating, ventilation and air-conditioning systems (HVAC) - investigate tri-generation whereby a CHP can } \\
\text { generate heat and cold for use on site }\end{array}$ \\
\cline { 2 - 2 } & Intelligent management systems: aeration of the activated sludge process \\
\cline { 2 - 2 } & Energy awareness campaigns \\
\cline { 2 - 2 } & Convert to heat pumps and solar water geysers for hot water requirements \\
\cline { 2 - 2 } & Increase efficiency in the transformation of energy and materials into products and services \\
\hline Biomass conversion to energy \\
supply & Wastewater sludge for sustainable bio-energy production avoids/offsets conventional energy use \\
\hline Changes in lifestyle & Changes in consumer behaviour and green procurements \\
\cline { 2 - 2 } & Increased awareness \\
\cline { 2 - 2 } & Systematic building design in terms of lighting, ventilation, HVAC systems, passive heating \\
\hline
\end{tabular}

http://dx.doi.org/10.4314/wsa.v41i2.12 
contribute the most significant emissions. The tool provides an analytical platform for comparing and contrasting different carbon-reducing strategies and scenarios. Once a baseline has been established, the DIY calculator can be used to determine the trend in the carbon footprint and to delineate what activity might have contributed to an increase or decrease in the carbon footprint.

\section{ACKNOWLEDGEMENTS}

The authors would like to thank the following organisations in the preparation of this paper: eThekwini Water and Sanitation for permitting use of the Northern and KwaMashu WWTWs as case studies in the application of the model, and the use of its data sets; the Centre of Expertise for awarding RHDHV the opportunity to develop the DIY carbon footprint assessment tool; and Royal HaskoningDHV for permitting the author to develop this manuscript.

\section{REFERENCES}

DEFRA (DEPARTMENT FOR ENVIRONMENT, FOOD AND RURAL AFFAIRS, UK) (2014) Measuring scope 3 carbon emissions - water and waste a guide to good practice: Defra/ DECC's greenhouse gas conversion factors for company reporting guidelines. URL: www.defra.gov.uk/environment/economy/businessefficiency/reporting/ (Accessed 14 August 2014).

GOVENDER D and MEIJER L (2012) eThekwini Water Services, the carbon footprint of eThekwini Water and Sanitation. URL: http:// www.coe.org.za (Accessed 21 April 2014).

GUO H, KOORNNEEF E and LUE B (2009) Dutch Approach: Energy Recovery from Sewage Sludge. Orbit, Amersfoort, The Netherlands.

GUPTA D and SINGH SK (2012) Greenhouse gas emissions from wastewater treatment plants: a case study of Noida. J. Water Sustainability 2 (2) 131-139.

STATE OF SCIENCE REPORT (2008) Energy and resource recovery from sludge. Global Water Research Coalition, Stirling, Australia. 